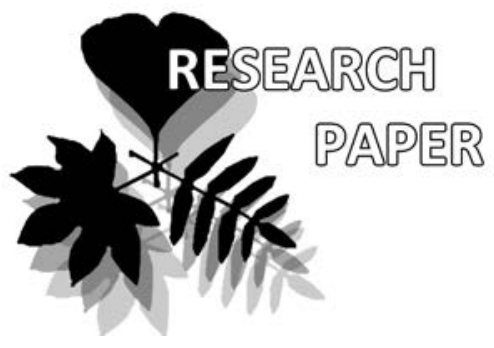

\title{
Changes of the Pinus koraiensis distribution in the south of the Russian Far East in the postglacial time
}

\author{
Pavel S. Belyanin* \& Nina I. Belyanina
}

Pavel S. Belyanin*

e-mail:@mail.ru

Nina I. Belyanina

e-mail: nibelyanina@yandex.ru

Pacific Institute of Geography FEB RAS, Vladivostok, Russia

* corresponding author

Manuscript received: 22.10 .2018

Review completed: 20.01.2019

Accepted for publication: 02.02.2019

Published online: 11.02.2019

\begin{abstract}
A B S T R A C T
The newly obtained palynological and chronostratigraphic data allowed a definite conclusion on the time of the first appearance of the Korean pine (Pinus koraiensis Siebold et Zucc.) in the southern Far East of Russia. Its further evolution has been traced through the postglacial interval. As follows from our studies, after the last stage of the Pleistocene cryochron had come to its end, the Korean pine expanded its range and gained in importance in the continental ecosystems of the Russian Far East. The species boundary shifts to the north were synchronous with episodes of climate changes. Soon enough the Korean pine occupied a prominent place in the vegetation: it became one of the leading components in spruce-fir forests with oak and elm in the Early Holocene. Intervals noted for an increase in its proportion in the vegetation coincided mostly with periods of greater heat supply. According to the obtained palynological data supported by radiocarbon dating results, it fell on the middle intervals of the Early and Middle Holocene, and also on the 2nd part of the Late Holocene. At that, the most diversified plant formations with the Korean pine were most typical of the Holocene optimum. The species importance was somewhat reduced at the time of a lower heat supply at the end of the Early Holocene, as well as at initial stages of the Middle and Late Holocene - the intervals marked by a reduced participation of the broadleaf species, while dark coniferous and small-leaved trees became more important.
\end{abstract}

Ke ywords : southern Far East of Russia, Korean pine, vegetation evolution, plant migrations in time and space, Holocene, environmental components

\section{P E 3 Ю M E}

Белянин П.С., Бемянина Н.И. Изменения распространения Pinus koraiensis на юге российского Аальнего Востока в послеледниковое время. В статье приводятся новые палинологические и хроностратиграфические Аанные, позволившие Аатировать появление и описать пространственновременную Аинамику сосны корейской (Pinus koraiensis Siebold et Zucc.) на юге Аальнего Востока России в послеледниковое время. Нами показано, что после завершения последней стадии плейстоценового криохрона, в континентальных экосистемах юга Аальнего Востока России началась экспансия сосны корейской. Ее ареал смещался к северу синхронно с улучшением кАиматических условий. Сосна корейская Аостаточно быстро заняла веАущую роль в растительности, став уже в раннем голоцене одним из основных компонентов елово-пихтовых цесов с Аубом и ильмом. Расширение ее участия в растительности соответствует периодам с Аучшей теплообеспеченностью, что согласно полученным нами палинологическим Аанным, подкрепленных результатами радиоуглеродного датирования, приходится на середину раннего и среднего, а также на вторую половину позднего голоцена. При этом, наиболее фмористически разнообразные растительные формации с сосной корейской получали развитие в оптимум голоцена. Сокращение ее роли в растительности фиксируется при снижении теплообеспеченности в конце раннего, а также на начальных стадиях среднего и позднего голоцена, когда снижалось участие широколиственных растений, но возрастала роль темнохвойных и мелколиственных пород.

КАючевые слова: юг Аальнего Востока, сосна корейская, эволюция растительности, пространственно-временные миграции растений, голоцен, манАшафтные компоненты
The Korean pine (Pinus koraiensis Siebold et Zucc.) belongs to the pine family (Pinaceae Lindl.), genus Pinus L. It is one of the chief forest-forming species in the south of the Far East of Russia - the region is among those, quite few in number, with barely disturbed primary forests still occurring (Krestov 2003). The species is included into the
Red List of Threatened Species developed by the International Union for Conservation of Nature (Thomas \& Farjon 2013).

It is not quite clear when the Korean pine first appeared in the continental ecosystems of the southern Far East of Russia in the postglacial time; nor its dynamics has been 
completely understood in the Holocene plant formations. According to the present views, the Last Pleistocene cryochrone (corresponding to Marine Isotope Stage 2) was marked by a major restructuring of the vegetation all over the Earth including the Sea of Japan basin. Under deteriorating climate conditions the south of Russian Far East was dominated by forests of spruce and fir, birch and larch with shrub birch (Korotky et al. 2005, Anderson et al. 2017), and a negligible presence of the Korean pine. The latter species was confined to the south of the Korean Peninsula and extended to the islands of Japan joined with the continent by a land bridge due to the lower sea level stand (Khershberg et al. 2013, Tsukada 1984, Igarashi 1993, Nakamura \& Krestov 2005).

The abundant pollen records recovered from sequences dated to the Late Pleistocene cryochrons lend support to the view that the Korean pine disappeared almost completely from the southern Far East of Russia. Nevertheless, it is quite possible that pollen grains of Pinus subgenus Haploxylon recovered from interstadial deposits in the southern Far East are attributable to Pinus koraiensis. That is suggested by the taxonomic composition of pollen spectra indicative of a wide occurrence of dark coniferous (spruce and fir) forests highly diversified in structure. The presence of the Japanese stone pine (Pinus pumila (Pall.) Regel) (similar to Pinus koraiensis in the pollen grain morphology) may be practically excluded as the species is light-demanding and poorly competitive; it can hardly compete with other trees and shrubs and does not form compact communities under a close canopy of trees (Kabanov 1977).

The biostratigraphic data have been obtained from studies of fluvial-lacustrine deposits (borehole 579, depth. $5.2 \mathrm{~m}$ ) dated by radiocarbon at $21402 \pm 453 \mathrm{cal} \mathrm{BP}$ (Ki2166); the proportion of Pinus koraiensis pollen in the spectra amounts to $6.2 \%$ (Belyanin \& Belyanina 2012). Individual pollen grains of Pinus koraiensis (Anderson et al. 2017) were recovered from the Lake Karasye sediments chronologically close to the above mentioned (20 599 \pm 83 cal BP, CAMS \# 73291). Pollen assemblages recovered from valley deposits in the middle reaches of the Bikin River dated at 17 $290 \pm 170$ cal BP (LU-7559) show the proportion of Pinus koraiensis pollen up to $17 \%$ (Razzhigaeva et al. 2017). The deposits sampled downstream the same valley (observation points 6204 and 6205) and dated by the radiocarbon to 21 $673 \pm 448 \mathrm{cal} \mathrm{BP}(\mathrm{Ki}-3293), 18$ 138 $\pm 288 \mathrm{cal} \mathrm{BP}(\mathrm{Ki}-3294)$, and $13173 \pm 112 \mathrm{cal} \mathrm{BP}(\mathrm{Ki}-3343)$ yielded only rare grains of the Korean pine pollen.

Though the evolution of the Russian Far East through the Late Pleistocene and Holocene has been investigated in considerable detail (Anderson et al. 2017, Alekseyev \& Golubeva 1980, Golubeva \& Karaulova 1983, Korotky 2002, Korotky et al. 2005, Mikishin et al. 2008, Pavlyutkin \& Belyanina 2002, Razjigaeva et al. 2018), the spatial-temporal migrations of vegetation constituents in the region are still insufficiently understood. That is true in particular for the time of the Korean pine appearance and its dynamics trough the post-glacial time. Most likely, it may be attributed to some gaps in biostratigraphic records not yet adequately investigated. Slight changes in the ranges of plants resulting from small-amplitude and short-term climatic fluctuations are hard to record. Besides, finding and opening the Early Holocene and Late Pleistocene sequences presents certain problems. All the above interferes considerably with reconstructing paleoenvironments and forecasting development of continental ecosystems in the Pacific landscape zone.

Most of earlier works tend to assign the Korean pine appearance in the southern Far East to the Late Holocene. According to Shumova and Klimanov (1989), its expansion started about $900 \mathrm{cal}$ yr BP, while Urusov (1999) considers the beginning of the Korean pine dispersal over the region to occur after $4000 \mathrm{cal}$. yr BP. In the opinion of Neustadt (1952) based on studies of pollen assemblages recovered from peat sequences, the Korean pine first appeared in the southern Sikhote-Alin foothills and in the East Manchuria Mountains as early as the Early Holocene 12 000-9500 BP, or about 13 800-10 $800 \mathrm{cal}$ BP. This opinion, however, could not be properly substantiated as the studied sections were too few in number and had not been dated by radiocarbon. It was much later that the first evidence of the Korean pine expansion onto the southern Far East of Russia in the Early Holocene were obtained (Pavlyutkin \& Belyanina 2002, Mikishin et al. 2008, Anderson et al. 2017, Belyanin 2017). However, no investigation aimed specially at the stated problem has been performed.

The present paper presents the first high-resolution record of the Korean pine evolution in the south of the Far East in the Holocene. The purpose of the present study is to date the Korean pine appearance and to reconstruct its participation in the regional vegetation through the postglacial time.

\section{OBJECT, MATERIAL AND METHODS}

When viewed in the context of the East Asian continental ecosystems, the Korean pine is a typical element of landscapes in mountain systems of the Sikhote-Alin, Manchurian-Korean Mountains, Changbai Plateau, Wanda mountains, and the Lesser Khingan Ridge (Kolesnikov 1954, 1956, Nakamura \& Krestov 2005). On the Islands of Japan it is found occasionally in the Central and Southern Japanese Alpes (Honshu Isl.), as well as on Shikoku Isl. (Ohwi 1965) (Fig. 1).

\section{Range and ecology}

The Korean pine range coincides closely with the boundaries of the Manchurian floristic province notable for the pine forests being a typical constituent of the ridge-andvalley landscapes (Komarov 1949). In the south of the Russian Far East forests of Korean pine are mostly confined to the altitudes between 200 and $900 \mathrm{~m}$ a.s.l. In the Northeastern China they grow at altitudes from 500 to 1300 m, while on the Korean Peninsula (Chun 1994), on Honshu and Shikoku (Ohwi 1965) islands the Korean pine occurs at elevations up to $2500 \mathrm{~m}$ a.s.l.

There are three ecological zones recognizable within the Korean pine range in the south of the Russian Far East. In the southern zone (the Manchurian-Korean Mountains, southern Sikhote-Alin offspurs) it appears as a codominant in the formations most diversified floristically 


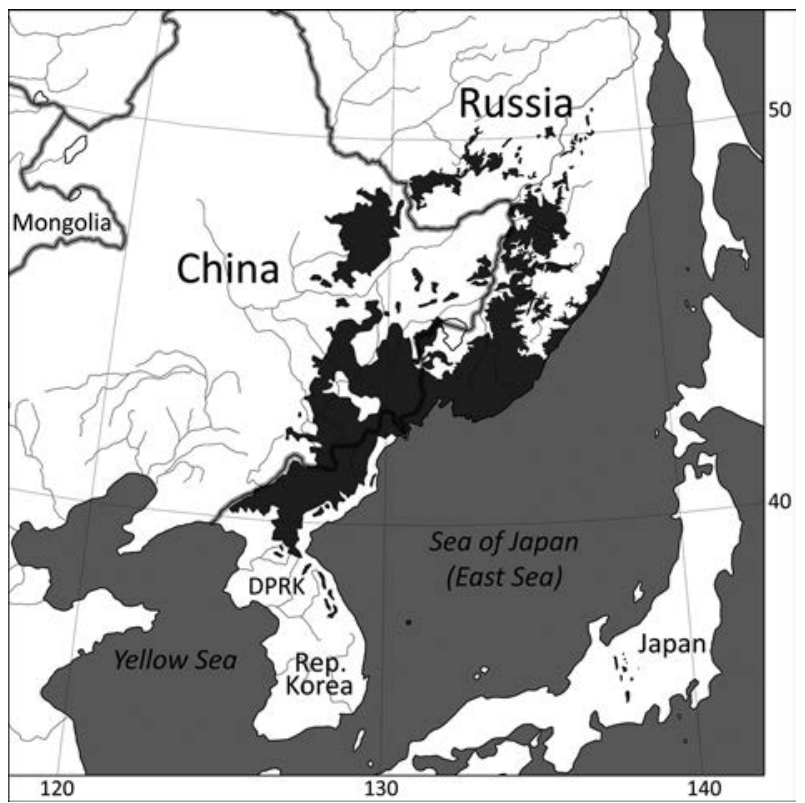

Figure 1 Distribution of forests with Pinus koraiensis (modified from Krestov et al. 2006)

and composed primarily of Carpinus cordata Blume, Abies bolophylla Maxim., Pinus densiflora Siebold et Zucc. and others. In the middle zone (the northeast of China, southern and middle Sikhote-Alin) the Korean pine is distinct for the best growth and technical characteristics. Here it is a constituent of mixed and dark coniferous forests. In the northern zone (the Northern Sikhote-Alin and Lesser Khingan mountains) the Korean pine proportion in the dark coniferous forests with larch is reduced and it does not occur above $250 \mathrm{~m}$ a.s.l. That may be attributed to the lower annual temperatures and an increased competition with plants of the boreal taiga flora (Kolesnikov 1954).

Although the Korean pine is distributed over a large enough area, the most favorable climatic conditions for its growth exist between $41^{\circ}$ and $49^{\circ} \mathrm{N}$ in North Korea and northeastern China (Kolesnikov 1954, Urusov et al. 2007). In the southern Far East of Russia the greatest part of its range belongs to the Amur River drainage basin and a smaller part - to the coast of the Sea of Japan.

The Korean pine occurrence mostly depends on the climate (Soloviev 1958) (Table 1). In the Sea of Japan coasts the regional climate is under control of the southern monsoon, the continental climate influence increasing from the coast inland. The leading factors that determine the composition and structure of the mixed forest with Pinus koraiensis are as follows: the maximum temperature of the warmest month; the mean temperature of the warmest quarter of a year; total precipitation of the wettest month (Zhang et al. 2014).

\section{Materials and methods}

The suggested reconstruction of the Korean pine migration in space and time in based on the concept of climatecontrolled migrations developed by Troitskiy (1979). The palynological and chronostratigraphic data have been obtained from observation points and sequences penetrated by boreholes and described in valleys and forelands of the Manchurian-Korean Mountains, southern and middle Sikhote-Alin (Fig. 2). The data were correlated using the stratigraphic scheme of the Quaternary suggested by the Subcomission on the Quaternary Stratigraphy and by the INTIMATE Working Group (Walker et al. 2012).

\section{Pollen analysis}

Pollen assemblages obtained by Belyanina from 132 samples permitted to trace changes in the Korean pine significance in the regional vegetation. The samples were prepared using the technique suggested by von Post (Pokrovskaya 1950). The specimens were viewed and photographically documented under the optical microscope Axio Scope A1 (Carl Zeiss). The pollen and spores were identified, when possible, to a level of species. In case of microfossils poorly identifiable by their micromorphology their genera or families were determined. The percentage of individual taxa was estimated separately for groups: arboreal pollen (trees and bushes - AP); herb and grass pollen together with dwarf shrubs (NAP); and spores. Proportion of aquatic plant pollen was calculated with reference to sum of land plant pollen.

\section{Chronology}

The chronology of changes in the Korean pine pollen proportion is based on radiocarbon dates and in their absence - on the stratigraphic correlation of palynological sequences. Tree and plant remains were dated by radiocarbon

Table 1. Extreme and optimum values of the most important climatic parameters that determine the range of Korean pine in the south of the Russian Far East (after Kolesnikov 1954)

\begin{tabular}{|c|c|c|c|}
\hline \multirow{2}{*}{ Parameter of climate } & \multicolumn{3}{|c|}{ Physical characteristics } \\
\hline & minimum & maximum & optimum \\
\hline Mean annual temperature, ${ }^{\circ} \mathrm{C}$ & 0 & +6 & - \\
\hline Extreme values of daily temperatures, ${ }^{\circ} \mathrm{C}$ & -50 & +40 & - \\
\hline Number of months in a year with mean temperature above $0^{\circ} \mathrm{C}$ & 6 & 8 & 7 \\
\hline Growing period, days & 150 & 200 & $170-180$ \\
\hline Duration of frost-free period, days & 100 & 170 & $120-150$ \\
\hline Degree day temperatures, ${ }^{\circ} \mathrm{C}$ & 2600 & $>3200$ & - \\
\hline Mean annual precipitation, $\mathrm{mm}$ & 500 & 1000 & $600-700$ \\
\hline Extreme values of mean annual rainfall in individual years, $\mathrm{mm}$ & 320 & $>1200$ & - \\
\hline Mean annual relative air humidity as recorded at 13 p.m., $\%$ & 60 & 72 & $<70$ \\
\hline Mean relative air humidity as recorded at 13 p.m. of the most rainy month (July or August), \%o & 68 & 91 & 75 \\
\hline $\begin{array}{l}\text { Mean relative air humidity as recorded at } 13 \text { p.m. of the most dry month in the growing period } \\
\text { (April or May), \%o }\end{array}$ & 41 & 45 & - \\
\hline
\end{tabular}




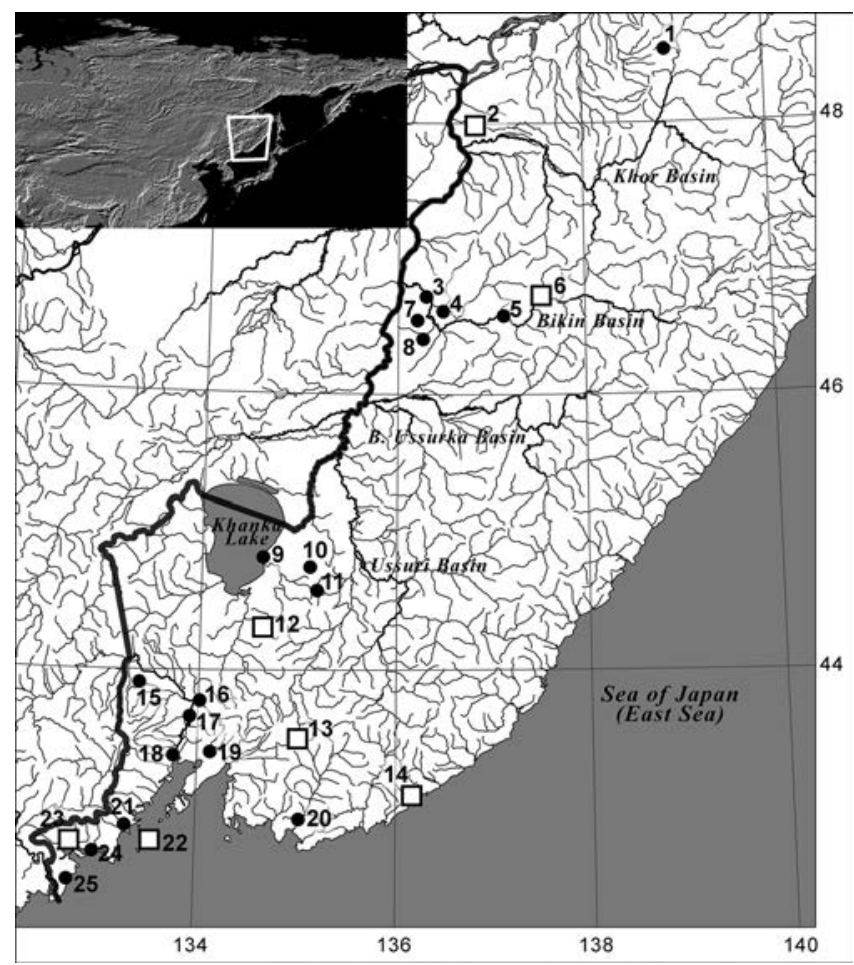

in the Lawrence Livermore Center of Accelerated MassSpectrometry of the National Laboratory, Department of Energy, the University of California (T.A. Brown), and also in the Laboratory of Geochronology, St.-Petersburg State University (Kh.A. Arslanov, F.B. Maksimov), and in Institute of Geology, Academy of Sciences of the USSR (N.N. Kovalyukh). The radiocarbon dates were calibrated into calendar ones using the «CalPal» program (Weninger et al. 2012) (Table 2).

\section{RESULTS}

The reconstructions of Korean pine first appearance and subsequent occurrence in the south of the Russian Far East are based on the pollen assemblages recovered from a series of sections dated by ${ }^{14} \mathrm{C}$ (see Fig. 2 for the location of the sections).

\section{Early Holocene}

The first evidence of the Korean pine presence was recorded in the sequence of the Sorochevka River floodplain (borehole 508, in the vicinities of Chkalovka Settlement). The sandy loam layer dated to $11003 \pm 186$ cal BP

Figure 2 Locations of the boreholes and observation points studied by authors (dots) and other researchers (squares): Khor River Basin: 1 - o.p. Stream Bolotisty; Kiya River Basin: 2 - o.p. Kiya; Bikin River Basin: 3 - o.p. 6022, 4 - o.p. 6010, 5 - o.p. 08/20-2008, 6 - o.p. 314, 7 - 6056, 8 - o.p. 6205; Upper Ussuri River and Khanka Lake Basin: 9 - bor. 579, 10 - bor. 508, 11 - o.p. 4074, 12 - o.p. 1438 ; South Primorye Region: 13 - bor. 613, 14 - o.p. Kit, 15 - o.p. Kazachka, 16 - o.p. 9119, 17 - o.p. 4005, 18 - bor. Utinoye Lake, 19 - o.p. $1706-17$, 20 - bor. 9, o.p. 9031 a, 21 - bor. 24-1, 22 - o.p. Stenina Isl., 23 - bor. 272, 24 -bor. Karasie Lake, 25 - o.p. 1508-1

Table 2. Radiocarbon dates

\begin{tabular}{|c|c|c|c|c|c|c|}
\hline $\begin{array}{l}\text { Boreholes (bor.), } \\
\text { observation points (o. p.) }\end{array}$ & $\begin{array}{l}\text { No on the } \\
\text { Fig. } 2\end{array}$ & Depth, m & Dated material & $\begin{array}{l}\text { Laboratory } \\
\text { number }\end{array}$ & ${ }^{14} \mathrm{C}$ age, $\mathrm{BP}$ & $\begin{array}{l}{ }^{14} \mathrm{C} \text {-calibrated } \\
\text { age, cal BP }\end{array}$ \\
\hline o. p. 6205 & 8 & 6.9 & wood & $\mathrm{Ki}-3293$ & $17990 \pm 200$ & $21673 \pm 448$ \\
\hline bor. 579 & 9 & 5.2 & humified loam & $\mathrm{Ki}-2166$ & $17840 \pm 200$ & $21402 \pm 453$ \\
\hline bor. Lake Karasye & 24 & $3.24-3.23$ & seeds, wood, tree moss & CAMS \# 73291 & $17160 \pm 40$ & $20599 \pm 83$ \\
\hline o. p. 6205 & 8 & 5.7 & wood & $\mathrm{Ki}-3294$ & $14800 \pm 100$ & $18138 \pm 288$ \\
\hline o. p. 6205 & 8 & 3.6 & wood & $\mathrm{Ki}-3298$ & $12300 \pm 100$ & $14459 \pm 361$ \\
\hline bor. 508 & 10 & 4.5 & wood & $\mathrm{Ki}-2171$ & $9680 \pm 130$ & $11003 \pm 186$ \\
\hline o. p. 4074 & 11 & 2.0 & buried soil & $\mathrm{Ki}-2140$ & $9600 \pm 110$ & $10944 \pm 171$ \\
\hline o. p. 6205 & 8 & 1.8 & wood & $\mathrm{Ki}-3293$ & $9270 \pm 60$ & $10440 \pm 99$ \\
\hline o. p. 9119 & 16 & 2.1 & wood & - & $9250 \pm 70$ & $10421 \pm 103$ \\
\hline o. p. 9119 & 16 & 1.6 & wood & - & $8960 \pm 80$ & $10079 \pm 112$ \\
\hline bor. 9 & 20 & 6.5 & plant detritus & $\mathrm{Ki}-3688$ & $8900 \pm 60$ & $10030 \pm 112$ \\
\hline o. p. Bolotisty Stream & 1 & 3.2 & peat & LU-8138 & $8620 \pm 90$ & $9644 \pm 99$ \\
\hline bor. Lake Karasve & 24 & $1.40-1.37$ & seeds, wood, charcoal & CAMS \# 73290 & $7550 \pm 40$ & $8374 \pm 23$ \\
\hline o. p. 4005 & 17 & 2.4 & plant detritus & $\mathrm{Ki}-2365$ & $7240 \pm 120$ & $8077 \pm 111$ \\
\hline o. p. 6010 & 4 & 1.7 & plant detritus & $\mathrm{Ki}-3269$ & $6660 \pm 70$ & $7537 \pm 52$ \\
\hline o. p. 4005 & 17 & 2.2 & plant detritus & $\mathrm{Ki}-2159$ & $6530 \pm 75$ & $7434 \pm 74$ \\
\hline o. p. 6056 & 7 & 2.9 & plant detritus & $\mathrm{Ki}-3256$ & $6090 \pm 70$ & $6988 \pm 116$ \\
\hline o. p. 6205 & 8 & 0.8 & peat & $\mathrm{Ki}-3372$ & $5120 \pm 80$ & $5859 \pm 94$ \\
\hline bor. Lake Karasve & 24 & $1.04-1.03$ & seeds, charcoal & CAMS \# 71814 & $5050 \pm 40$ & $5813 \pm 63$ \\
\hline bor. Lake o3. Utinoye & 18 & $4.71-4.68$ & wood, charcoal & CAMS \# 73295 & $5000 \pm 80$ & $5763 \pm 98$ \\
\hline bor. Lake Karasye & 24 & $0.77-0.74$ & seeds & CAMS \# 74346 & $4890 \pm 40$ & $5632 \pm 26$ \\
\hline o. p. $1706-17$ & 19 & $1.86-1.89$ & buried soil & LU-8780 & $4650 \pm 110$ & $5350 \pm 160$ \\
\hline o. p. Kazachka & 15 & 1.2 & wood & DVGU-TIG-29 & $4472 \pm 75$ & $5119 \pm 134$ \\
\hline bor. Lake Karasye & 24 & $0.67-0.60$ & seeds & CAMS \# 73288 & $4300 \pm 40$ & $4894 \pm 44$ \\
\hline o. p. $9031 \mathrm{a}$ & 20 & 2.4 & wood & $\mathrm{Ki}-3686$ & $4210 \pm 60$ & $4736 \pm 92$ \\
\hline bor. Lake Utinoye & 18 & $3.47-3.45$ & wood & CAMS \# 76800 & $3920 \pm 40$ & $4329 \pm 64$ \\
\hline bor. Lake Karasye & 24 & $0.45-0.43$ & seeds & CAMS \#74344 & $3870 \pm 40$ & $4311 \pm 71$ \\
\hline o. p. $1706-17$ & 19 & $0.73-0.7$ & buried soil & LU-8779 & $3020 \pm 100$ & $3190 \pm 130$ \\
\hline bor. Lake Utinoye & 18 & $2.23-2.21$ & plant detritus & CAMS \#76799 & $2510 \pm 60$ & $2589 \pm 109$ \\
\hline o. p. $1508-1$ & 25 & $2.88-2.73$ & buried soil & LU-7961 & $2460 \pm 100$ & $2543 \pm 138$ \\
\hline o. p. 6022 & 3 & 1.6 & plant detritus & $\mathrm{Ki}-3270$ & $2350 \pm 40$ & $2398 \pm 49$ \\
\hline o. p. 4005 & 17 & 1.8 & wood & $\mathrm{Ki}-3678$ & $1930 \pm 40$ & $1883 \pm 43$ \\
\hline o. p. 1508-1 & 25 & $1.52-1.44$ & buried soil & LU-7960 & $1930 \pm 100$ & $1880 \pm 130$ \\
\hline bor. Lake Utinoye & 18 & $1.30-1.27$ & wood, leaves & CAMS \#76798 & $1810 \pm 60$ & $1736 \pm 80$ \\
\hline o. p. $1508-1$ & 25 & $0.65-0.57$ & buried soil & LU-7959 & $1360 \pm 60$ & $1280 \pm 60$ \\
\hline
\end{tabular}




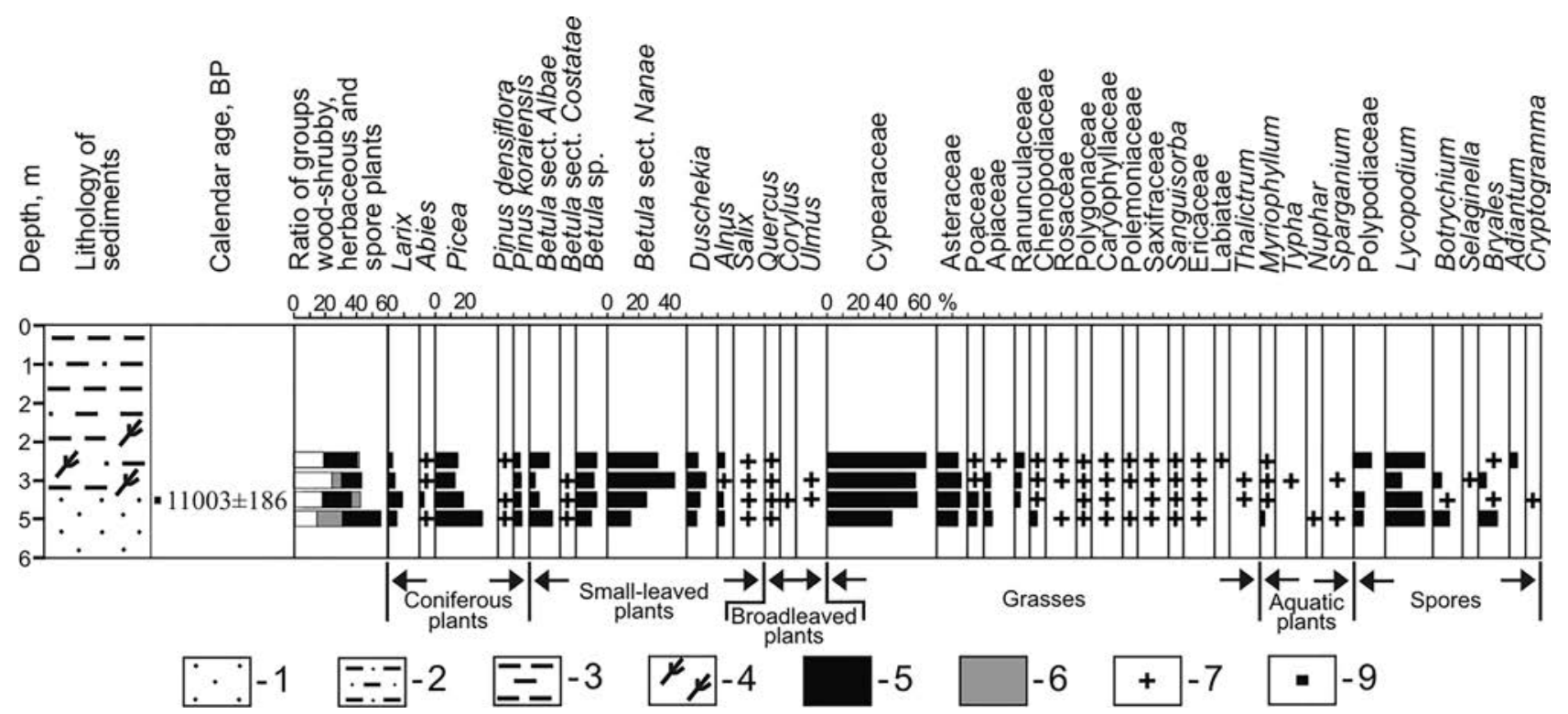

Figure 3 Pollen diagram from borehole 508. 1 - sand, 2 - sandy loam, 3 - loam, 4 - plant detritus. Relationship between plant groups: 5 - trees and shrubs, 6 - herbs and dwarf shrubs, 7 - spores, 8 - the taxa present in the assemblage in amounts less than $3 \%$. 9 - samples for ${ }^{14} \mathrm{C}$ analysis.

(Ki-2171) (see Table 2) yielded a pollen assemblage that indicates a subdominant position of the Korean pine $(5 \%)$ in the coniferous group including also Picea sp., Larix sp., and Abies sp. In the of small-leaved species group dominant are pollen of Betula sect. Nanae, Betula sp., as well as Duschekia sp. Some other trees - Salix sp., Alnus sp., Betula sect. Albae and Betula sect. Costatae - are present as accompanying species. The broadleaved trees are represented by Quercus sp., Corylus sp. and Ulmus sp. Typically, Sphagnum sp. spores are found in abundance (Fig. 3). The origin of those deposits is unquestionably indicated by the presence of the diatom assemblage characteristic of floodplains in the sample taken from $5 \mathrm{~m}$ depths.

The above data are complemented with the results of biostratigraphic studies of bluish-gray sandy loam exposed in the river bank scarp north of Kronshtadka settl. (observation point 4074) upstream of the above-described site (borehole 508) The proportion of Pinus koraiensis pollen in the assemblage amounts to $2.3 \%$, the age of enclosing deposits is $10994 \pm 171 \mathrm{cal} \mathrm{BP}(\mathrm{Ki}-2140)$ (see Table 2).

In the north of the Primorye region, in the lower reaches of the Bikin River (o.p. 6205), a layer of bluishgray loam dated to $10440 \pm 99 \mathrm{cal} B P$ yielded a pollen assemblage distinct for a pronounced dominance of coniferous and small-leaved plants. Pinus koraiensis prevails in the coniferous group $(29.4 \%)$. It is accompanied with a few broad-leaved, such as Ulmus, Picea, Quercus, Corylus and Tilia sp. Small-leaved plant microfossils are present in a considerable proportion - Betula sp. (12.5\%), Betula sect. Nanae $(30.9 \%)$, Betula sect. Albae (up to $13.1 \%$ ), Duschekia (up to $9.2 \%$ ) and Alnus (up to $13.8 \%$ )

The Korean pine presence has been documented also in the early Holocene deposits in the lower reaches of the Razdolnaya River, at the Popovka River mouth (o.p. 9119). A sample taken at a depth $2.1 \mathrm{~m}$ from blue-gray sandy loam with wood remains dated by ${ }^{14} \mathrm{C}$ to $10421 \pm 103 \mathrm{cal} \mathrm{BP}$ con- tains the Korean pine in proportion of $2 \%$; its amount rises steeply upwards up to $65 \%$ at a depth of $1.6 \mathrm{~m}$ (10 079 \pm 112 cal BP) (Fig. 4).

Similar biostratigraphic materials were obtained in studies of blue-gray loam with plant remains at the mouth of the Partizanskaya River near Golubovka village (borehole 9); there the Pinus koraiensis proportion amounted to $23.6 \%$. The age of the enclosing sediments is indicated by the ${ }^{14} \mathrm{C}$ date $9672 \pm 87$ cal BP, Ki-3688) (Pavlyutkin \& Belyanina 2002). A similar pollen assemblage with Pinus koraiensis proportion of $26.7 \%$ has been obtained from a depth of $6 \mathrm{~m}$ at the Tumannaya Rover mouth (borehole 103).

In the Middle Sikhote Alin, at an altitude of $650 \mathrm{~m}$ a.s.l. there were dated and sampled loose deposits of the Bolotisty Creek (the upper part of the Khor River drainage basin). A sample of a heavily decomposed brown peat from a depth of $3.2 \mathrm{~m}$ was dated by radiocarbon to $9644 \pm 99 \mathrm{cal}$ BP (LU-8138). The pollen assemblage recovered from the peat is dominated by Picea, with pollen grains of Abies and Larix also present, and the proportion of Pinus koraiensis is $2.3 \%$ only. In the group of small-leaved species shrubs Duschekia and Betula sect. Nanae are dominant, along with some tree species - Betula sect. Costatae, Betula sect. Albae, and Alnus. Pollen of broadleaf trees - Quercus, Ulmus and Tilia - is rather scarce (Belyanin et al. 2018).

Previously, when studying dark-gray silts with wood fragments in the section of the Chernigovka River terrace (o.p. 1438), Korotky found a proportion of the Korean pine in the total assemblage to be high - up to $15 \%$; the sample was dated by radiocarbon to $9160 \pm 108 \mathrm{cal}$ BP (Korotky et al. 1980). At the mouth of the Vinogradnaya River at its entering the Expedition Bay (borehole 272) Mikishin identified a pollen complex distinct for a high percentage of Pinus koraiensis (59-64\%), accompanied by an assortment of broad-leaved and small-leaved plants. The enclosing sediments are dated to $8871 \pm 93 \mathrm{cal} \mathrm{BP}$ (Mikishin et al. 2008). In 


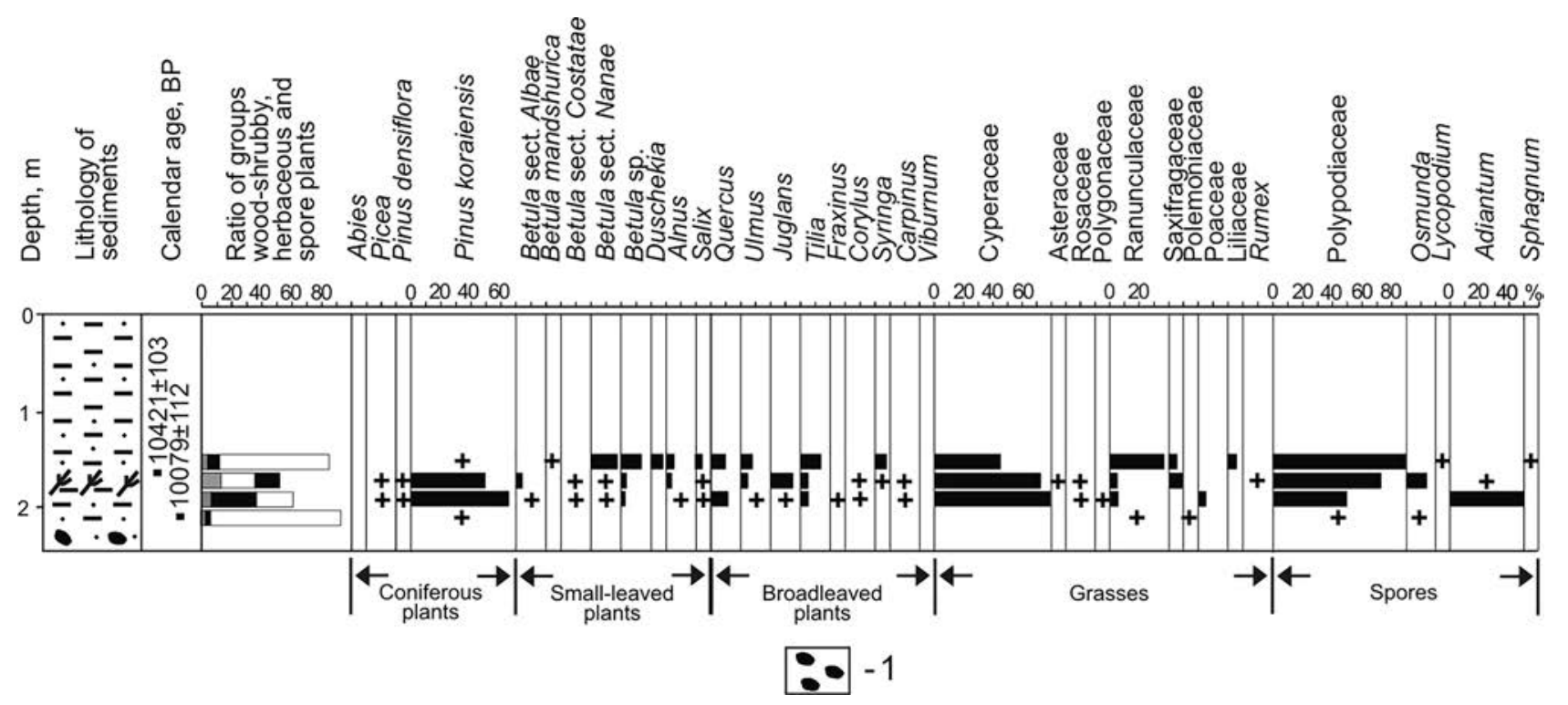

Figure 4 Pollen diagram from the sequence in o.p. 9119. For explanation see Fig. 3.1 - pebbles

the extreme south of the Russian Far East there were single grains of the Korean pine pollen recovered from bottom sediments of Karasye Lake dated by ${ }^{14} \mathrm{C}$ to $8374 \pm 23 \mathrm{cal} \mathrm{BP}$ (CAMS \# 73290) (Anderson et al. 2017).

\section{Middle Holocene}

The beginning of the next (Middle Holocene) stage in the Korean pine evolution in the region has been documented in the lower reaches of the Razdolnaya River (o.p. 4005). There a sand layer with plant remains (dated by ${ }^{14} \mathrm{C}$ to $8077 \pm 111 \mathrm{cal} \mathrm{BP}, \mathrm{Ki}-2365)$ yielded a pollen assemblage dominated by Pinus koraiensis (30 \%) and Quercus (35-42\%). A practically identical pollen assemblage was obtained from the same sequence slightly higher; it is distinct for the prevalence of moderately thermophilic plants - Quercus, Ulmus, Juglans mandshrica Maxim., and Tilia, while the Pinus koraiensis proportion is reduced to $14 \%$ (its ${ }^{14} \mathrm{C}$ age is $7290 \pm 88 \mathrm{cal}$ $\mathrm{BP}, \mathrm{Ki}-2159)$. Such an assortment of taxa suggests polydominant forests with the Korean pine to be widely distributed in the surrounding landscapes (Pavlyutkin \& Belyanina 2002).

The Korean pine occurred also in the landscapes of near-shore islands in the Sea of Japan. That is suggested by the pollen assemblage from the marine mud with mollusk shells sampled on Stenin Island $\left({ }^{14} \mathrm{C}\right.$ age $\left.-7252 \pm 46 \mathrm{cal} \mathrm{BP}\right)$; the amount of the Korean pine in it was $8 \%$ (Lyashchevskaya 2016).

A similar pollen assemblage with amount of Pinus koraiensis varying between $19.7 \%$ and $38.6 \%$ was described in the lower reaches of the Poyma River, in the section of a steep bank (borehole 24-1), between 3.8 and $2.0 \mathrm{~m}$ from the top. The age of the sediments may be inferred from the assemblage of fluvio-marine diatoms that inhabited the near-shore water there at the time of high stand of the sea level (the Holocene optimum). The leading position in the studied assemblage belonged to the pollen of broadleaved trees, including Quercus, Ulmus, Juglans and Carpinus sp. They are accompanied by grains of Syringa sp., Corylus,
Acer sp., Tilia sp., Weigela sp. and Fraxinus, as well as by some representative of Araliaceae Juss. and Rosaceae Juss. families (Belyanin 2017).

As follows from the palynological studies of the sediments in the lower reaches of the Bikin R., the Korean pine presence in the pollen assemblages was much lower. To take but a few examples, its proportion amounts to $2.1 \%$ in the sample taken from the high floodplain of the Alchan River (o.p. $6010,{ }^{14} \mathrm{C}$ age is $\left.7537 \pm 52 \mathrm{cal} \mathrm{BP}, \mathrm{Ki}-3269\right)$; in the sample taken from the high floodplain of the Burlitovka River (o.p. 6056, 6988土116 cal BP, Ki-3256) it is $2.3 \%$; deposits of the Kontrovod River terrace (o.p. $6205,{ }^{14} \mathrm{C}$ $5859 \pm 94 \mathrm{cal} \mathrm{BP}, \mathrm{Ki}-3372$ ) yielded a slightly higher value $3.6 \%$. The pollen assemblages are dominated by Quercus and Ulmus with accompanying dark coniferous, smallleaved, and broad-leaved plants (Belyanina 2005).

Similarly small amount of Pinus koraiensis pollen (2.3\%) was recovered from the Karasye Lake bottom sediments (silt) ${ }^{14} \mathrm{C}$-dated at $5813 \pm 63 \mathrm{cal} \mathrm{r}$ BP, CAMS \# 71814, and $5632 \pm 26 \mathrm{cal}$ BP, CAMS \# 74346. In the Utinoye Lake sediments of approximately same age $\left({ }^{14} \mathrm{C} 5763 \pm 98 \mathrm{cal} \mathrm{BP}\right.$, CAMS \# 73295) it is as high as $9.8 \%$ (Anderson et al. 2017).

Earlier, in the course of the biostratigraphic works in the Kit Bay, a peat layer yielded a pollen spectrum indicative of widely distributed forests of oak and Korean pine. The Pinus koraiensis pollen makes up to $65 \%$ of the total. The enclosing deposits are dated at $5760 \pm 90 \mathrm{cal} \mathrm{BP}$ (Razjigaeva et al. 2018).

A high proportion of Pinus koraiensis pollen (33.7\%) was recorded in a sample taken from a terrace of the Knevichanka River (o.p. 1706-17) and dated at 5360 $160 \mathrm{cal}$ BP (LU-8780).

A pollen assemblage recovered from deposits of a high floodplain of the Bolshaya Kazachka River (Kazachka o.p.) displayed the Korean pine presence in a reduced quantity $-1.8 \%$. The sample taken from a depth of $1.2 \mathrm{~m}$ from the surface is composed of brownish-gray sandy loam. Its ${ }^{14} \mathrm{C}$ age is $5119 \pm 134 \mathrm{cal} \mathrm{BP}$, DVGU-TIG-29). The bulk of 
the pollen consists of Betula sect. Albae, Betula sect. Costatae, Betula sp. and Duschekia sp. (Pavlyutkin et al. 1984).

A sandy silt member with plant detritus exposed in the Partizanskaya River bank (o.p. 9031a) was palynologically studied and dated by ${ }^{14} \mathrm{C}$ to $4736 \pm 92 \mathrm{cal} \mathrm{BP}(\mathrm{Ki}-3686)$. The pollen assemblage is noted for an increased proportion of the Korean pine pollen (up to 57 \%) (Pavlyutkin \& Belyanina 2002). Similar pollen spectra were found in the bottom sediments of Utinoye Lake, the proportion of Pinus koraiensis pollen rising to $11.9 \%$ (14C $4356 \pm 59$ cal BP, CAMS \# 75544) (Anderson et al. 2017).

\section{Late Holocene}

We can gain some idea of the Korean pine presence in plant formations at the beginning of Late Holocene from the pollen assemblage recovered from bottom deposits of Karasye Lake (an algal mud member dated by ${ }^{14} \mathrm{C}$ to 4311 $\pm 71 \mathrm{cal} \mathrm{BP}$, CAMS \# 73288). The Korean pine pollen comes in it to $14.8 \%$ of the total (Anderson et al. 2017).

In the north of the considered region the Korean pine pollen was recorded, though in smaller quantities $(7.3 \%$, according to Belyanin 2013) in the floodplain deposits of the Bikin River (the middle reaches, o.p. 08/20-2008). Similar pollen spectra have been obtained from the floodplain sequences on the interfluve of the Khor and Kiya rivers $\left({ }^{14} \mathrm{C} 4089 \pm 145 \mathrm{cal} \mathrm{BP}\right)$ (Bazarova et al. 2008).

A high proportion of the Korean pine pollen (up to $28 \%$ ) was recorded in the Larchenkov swamp sediments (Shkotovo Plateau). About $3840 \pm 140 \mathrm{cal} \mathrm{BP}$ the pine was the dominant species in mixed forests with the participation of birch (Razjigaevaa et al. 2016).

Similar palynological data were inferred from an analyzed sample from the Knevichanka River terrace (o.p. 170617). The Korean pine pollen occurs there in abundance (up to $38.4 \%$ ), and the enclosing deposits were dated by radiocarbon at $3190 \pm 130 \mathrm{cal} \mathrm{BP}$ (LU-8779).

A high content of the Korean pine pollen, $22.1 \%$, was recorded in the bottom sediments of Utinoye Lake $\left({ }^{14} \mathrm{C}\right.$

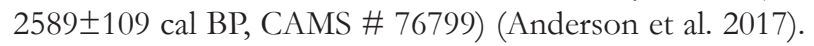
Marine sediments studied in a beach ridge at the Tumannaya River mouth (o.p. 1508-1) are composed of fine sand with plant detritus; they appeared to be close in age to the abovementioned $\left({ }^{14} \mathrm{C} 2540 \pm 130 \mathrm{cal} \mathrm{BP}, \mathrm{LU}-7961\right)$ and revealed a higher proportion (up to $24 \%$ ) of the Korean pine pollen.

A pollen assemblage absolutely dominated by Pinus koraiensis (up to $51.1 \%$ ) has been obtained in the lower reaches of the Bikin (o.p. 6022) with Picea, Betula sect. Albae, Ulmus, Quercus and Juglans present as accompanying species. The sediments were dated at $2398 \pm 49 \mathrm{cal} \mathrm{BP}(\mathrm{Ki}-3270)$.

The analysis of peat from the Razdolnaya River floodplain (o.p. 4005) dated at $1883 \pm 43 \mathrm{cal} \mathrm{BP}(\mathrm{Ki}-3678)$ also revealed a high percentage of Pinus koraiensis pollen (22.4\%) (Pavlyutkin \& Belyanina 2002). The paleobotanical investigations performed on the Utinoye Lake bottom sediments $\left({ }^{14} \mathrm{C} 1736 \pm 80 \mathrm{cal}\right.$ BP, CAMS \# 76798) revealed the Korean pine proportion as high as $18.3 \%$; that result is similar to the above cited, as well as to those obtained on the Shkotovo Plateau (Razjigaeva et al. 2016).

In the north of the region pollen assemblage recovered from a high floodplain sequence on the Bikin River is distinct for an exceedingly high proportion of Pinus koraiensis $-72.5 \%$ (Belyanin 2013). Its high values (27\%) have been also documented by Razjigaeva et al. (2017) in the Larchenkovo swamp deposits dated at $240 \pm 160 \mathrm{cal} \mathrm{BP}$.

\section{DISCUSSION}

The obtained pollen records dated on organic remains to $11000-10500$ cal BP contain grains of Pinus koraiensis pollen (Fig. 5). The fact agrees well with evidence on the global climate and environment amelioration at that time (Korotky et al. 2005, Bezrukova et al. 2005, Anderson et al. 2017, Belyanin et al. 2018) which led to essential changes in the plant formation structure due to the beginning of the plant migrations northward. At that time the environments were favorable for a wide distribution of the Korean pine under the forest canopy. The ecosystems began to acquire gradually their modern appearance.

In the early Holocene the Korean pine presence in forest formations in the Middle Sikhote-Alin foothills was still insignificant. Farther south, however, in the southern Sikhote-Alin ridges and in the East Manchuria Mountains it became one of codominants in dark coniferous-smallleaved forests with Mongolian oak and elm. That is strongly suggested by the pollen records where the proportion of the Korean pine pollen is notably greater than in valley deposits of the Middle Sikhote Alin. The data are in good agreement with those on the Baikal vicinities where an expansion of another pine species - Siberian stone pine (Pinus sibirica Du Tour) began $11000 \mathrm{cal} \mathrm{BP}$ (Bezrukova et al. 2005).

A greater proportion of the Korean pine pollen in the Early Holocene pollen assemblages documented in the Southern Primorye (Maritime) regions suggests the species came to the Sikhote-Alin and Manchuria-Korean mountains from the Korean Peninsula where environment were favorable for the vegetation even at MIS 2 time (Tsukada 1984, Nakamura \& Krestov 2005).

The transition from the Early to Middle Holocene was marked by a short-term cooling that resulted in the Korean pine being replaced in part by more cold-tolerant conifers. In the mountain ecosystems, in particular on north-facing slopes, the Korean pine (in common with broadleaved species) gave largely way to fir and spruce. Its presence was more considerable still in the Southern Primorye plant formations.

The heat supply continued to rise through the Middle Holocene which led to the shift of natural zones northward by $200-400 \mathrm{~km}$ (Khotinsky 1977). According to the data published by A.A. Velichko (2012), the global temperatures at the Holocene optimum were $0.7-1^{\circ} \mathrm{C}$ above those of today. In all probability, the rise in temperature could be as great as $3-5^{\circ} \mathrm{C}$ in Primorye (Maritime territory) (Korotky et al. 1999), and $2-3{ }^{\circ} \mathrm{C}$ in the south of the Korean Peninsula (Sohn 1984).

As a result of a rise of mean annual temperatures the Korean pine increased notably its presence in the south of the Russian Far East. Plant formations were more diversified in species composition as compared with that of the present days. Quite probably, they included species inhabi- 


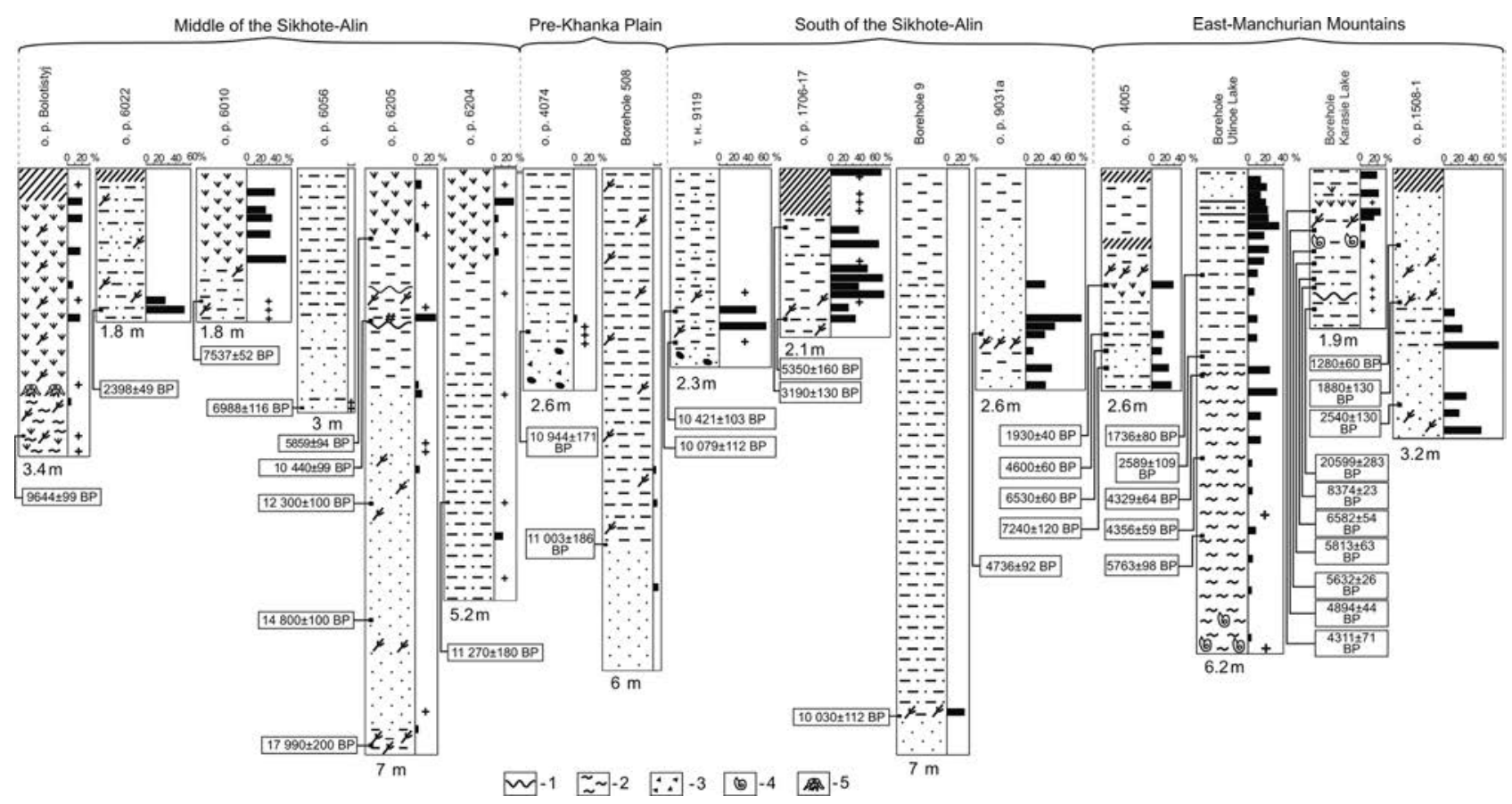

Figure 5 The presence of the Korean pine pollen in assemblages studied in the Holocene sequences (boreholes and observation points) in the southern Far East of Russia. For explanation see Fig. 3. 1 - gap in sedimentation, 2 - mud, 3 - gravel, 4 - marine shells, 5 - stump horizon

ting at present North Korea (north of $40^{\circ} \mathrm{N}$ ) and eastern regions of Mongolia; some of the genera were noted for a considerable species diversity.

It should be noted, that in a drier climate in the mountains in northeastern China, near Lake Sihaylongwan, the Korean pine began to spread $\sim 6600 \mathrm{cal} \mathrm{BP}$., and became one of the main forest-forming species $\sim 5200 \mathrm{cal} \mathrm{BP}$ (Stebich et al. 2015). In the mountains of Changbaishan, the Korean pine expansion occurred $\sim 5000{ }^{14} \mathrm{C} \mathrm{BP}, 5800 \mathrm{cal}$. BP, and about Lake Qingbohu (Jingbo) $5400 \mathrm{cal}$. BP (Li et al. 2011).

Similar processes are known to take place in the NearBaikal region where the Siberian stone pine was one of the main forest-forming species $\sim 6800 \mathrm{cal} \mathrm{yr} \mathrm{BP} \mathrm{(Danko} \mathrm{et} \mathrm{al.}$ 2009). The spatial migrations of plants were recorded also in the Middle Holocene on the Isles of Japan. For example, about 7800 cal BP Larix cajanderi disappeared from the flora of Hokkaido Island, and dark coniferous forests were replaced by oak forests with Quercus crispula Blume between 7800 and 5900 (Igarashi 1996), while warm temperate evergreen forests spread considerably over the archipelago from south to north (Tsukada 1984).

The cooling that started at the end of the middle Holocene aggravated the competition between the Korean pine and more cold-tolerant species like spruce and fir, which again resulted in a shrinking areas under pine forests.

Fluctuations of the Korean pine range occurred in the Late Holocene against the background of an unstable climate and gradually lowering heat supply (Wanner et al. 2008). The newly obtained palynological data suggest some wave-like fluctuations of the pine proportion in the plant formations.

A cooling at the beginning of the Late Holocene induced a wide expansion of dark coniferous and small-leaved plants along with a decrease of the Korean pine presence in the vegetation. The general trend towards cooling was interrupted once by a short-term warming. It was marked by a rising importance of the Korean pine in the mountain landscapes. In all probability, it was a co-dominant species in the plant formations with Pinus densiflora, Quercus mongolica Fisch. ex Ledeb., Abies holophylla, Abies neprolepsis (Trautv.) Ma$\mathrm{xim}$. and other trees. Similar processes took place in the ForeBaikal region 2600-1800 cal BP, when forests of the Siberian stone pine gained essentially in area (Bezrukova 2009).

Later on, the subsequent decline in the heat supply led to a transformation of pine-broadleaved forests into pinedark coniferous and small-leaved ones as the Korean pine had been replaced by spruce and fir, along with a lowering of its altitudinal boundary (tree line).

Another short-term warming (Wanner et al. 2008) correlatable with a Medieval Climate Anomaly and long-known in mid-latitudes took place in the second part of the Late Holocene. It resulted in an expansion of polydominant forests (with a notable proportion of the Korean pine) in ecosystems of the Sikhote Alin and East Manchuria Mountains. It may be safely suggested that Pinus densiflora, Betula sect. Albae, Betula sect. Costata, Betula davurica Pall., Abies holophylla, Carpinus cordata and some other plants were present as co-dominants.

In the Late Holocene the Korean pine position in the vegetation of the southern Far East of Russia was increasingly stabilized. It became the main forest-forming species in the polydominant forests of the southern Sikhote-Alin and East Manchuria Mountains; in the middle SikhoteAlin (and above 700-900 $\mathrm{m}$ in the southern mountains) it is among forest-forming trees in forests of fir and spruce with a limited presence of other broad-leaved and smallleaved species. 


\section{CONCLUSIONS}

The palynological and chronostratigraphic data obtained in the course of our works gave grounds for dating the Korean pine appearance in the south of the Russian Far East to 11 000-10 $500 \mathrm{cal} \mathrm{BP}$ and for reconstructing changes in its proportion in the continental ecosystems of the region through the postglacial time. Fluctuations in the proportion of the Korean pine pollen in the studied pollen assemblages suggest its fast response to climate changes.

There is strong evidence that the range of the Korean pine expanded northwards as far as the south of the Russian Far East at the transition from MIS 2 cryochron to the thermochron (the Holocene beginning). The continental ecosystems of the Pacific landscape zone began to acquire their modern outlook, with the Korean pine becoming their principal constituent in the southern Sikhote-Alin and East Manchuria Mountains. That interval (MIS 2 to MIS 1 transition) corresponds to the time of coniferous-broadleaved forest recovery after the cold epoch had come to its end.

The Korean pine continued strengthening its position in the regional vegetation through the Middle Holocene, the process being occasionally interrupted with short-term coolings. In the southern Sikhote Alin and East Manchuria Mountains the species became the main element of the coenoses in polydominant forests of complex structure, while in the middle Sikhote Alin it formed a component of mixed forests in association with small-leaved trees, Yezo spruce, Khingan fir and a few broad-leaved species.

In the Late Holocene the less stable climatic conditions account for differently directed (mostly from north to south and vice versa) migrations of the Korean pine in the south of the Far East. The range of the species increased in area at the end of the Late Holocene due to an amelioration of natural conditions, its outlines being close to those of today. The natural ecosystems acquired their modern appearance. The species composition of the vegetation, however, was still poorer than that of the Holocene optimum.

\section{ACKNOWLEDGEMENTS}

The author is grateful to Khikmatulla A. Arslanov (Saint Petersburg State University) for radiocarbon dates and Anatoly V. Lozhkin (Northeastern Integrated Scientific-Research Institute) for field assistance.

\section{LITERATURE CITED}

Alekseyev, M.N. \& L.V. Golubeva 1980. On the stratigraphy and paleogeography of the Upper Pleistocene. Bulleten' Komissii po izucheniyu chetvertichnogo perioda 50:96-107 (in Russian). [А^ексеев М.Н., Голуббева А.В. 1980. К стратиграфии и палеогеографии верхнего плейстоцена южного Приморья / / Бюмлетень Комиссии по изучению четвертичного периода. № 50. С. 96-107].

Anderson, P.M., P.S. Belyanin, N.I. Belyanina \& A.V. Lozhkin 2017. The vegetation evolution on the western coast of the Peter the Great Gulf in the Late Pleistocene Holocene. Tikhookeanskaya Geologiya 36(4):206-215 (in Russian). [Андерсон П.М., Белянин П.С., Белянина Н.И., Аожкин А.В. 2017. Эволюция растительного покрова западного побережья залива Петра Великого в позАнем плейстоцене-голоцене // Тихоокеанская геология. Т. 36, № 4. С. 206-215].
Bazarova, V.B., M.A. Klimin, L.M. Mokhova \& L.A. Orlova 2008. New pollen records of Late Pleistocene and Holocene changes of environment and climate in the Lower Amur River basin, NE Eurasia. Quaternary International 179(1):9-19.

Bezrukova, E.V., S.K. Krivonogov, A.A. Abzayeva, K.E. Vershinin, P.P. Letunova, L.A. Orlova, H. Takahara, N. Mieshi, T. Nakamura, S.M. Krapivina \& K. Kavamuro 2005. Environments and climate of the Prebaikalian region in the Late Glacial and Holocene based on interdisciplinary studies of peatlands. Geologiya i geofizika 46(1): 21-33 (in Russian). [Безрукова Е.В., Кривоногов С.К., Абзаева А.А., Вершинин К.Е., Аетунова П.П., Орлова А.А., Такахара Х., Миеши Н., Накамура Т., Крапивина С.М., Кавамуро К. 2005. Аандшафты и климат Прибайкалья в позАнеледниковье и голоцене по результатам комплексных исследований торфяников // Геология и геофизика. Т. 46, № 1. С. 21-33].

Belyanin, P.S. 2013. Evolution of geosystems in the Bikin River drainage basin (Far East of Russia) in the Middle and Late Holocene. Geographiya i Prirodnye Resursy 1:105-111. (in Russian). [Бемянин П.С. 2013. Развитие геосистем бассейна р. Бикин (Аальний Восток) в среднем и позАнем голоцене / / География и природные ресурсы. № 1. С. 105-111].

Belyanin, P.S. 2017. Korean pine - the main component of natural complexes in the south of Far East in the Holocene. In: Geosystems of North-Eastern Asia: territorial organization and dynamics (P.Ya. Baklanov, ed.), pp. 84-89. Pacific Institute of Geography FEB RAS, Vladivostok. (in Russian). [Белянин П.С. 2017. Сосна корейская - основной компонент природных комплексов юга АаАьнего Востока в голоцене / / Геосистемы в Северо-Восточной Азии: территориальная организация и Аинамика / пол ред. П.Я.Бакланова, Владивосток: Тихоокеанский институт географии АВО РАН. С. 84-89].

Belyanin, P.S. \& N.I. Belyanina 2012. On the Khanka depression vegetation evolution and its mountain framing in the Late Holocene-Neopleistocene (from palynological data). Tikhookeanskaya Geologiya (31)2: 96-100 (in Russian). Белянин П.С., Белянина Н.И. 2012. К эволюции растительного покрова Приханкайской впадины и ее горного обрамления в позднем неоплейстоцене-гомоцене (по палинологическим данным) // Тихоокеанская геология. Т. 31, № 2. С. 96-100].

Belyanin, P.S., V.V. Ivanov, S.V. Lesnov, N.I. Belyanina, Kh.A. Arslanov \& F.E. Maksimov 2018. Biostratigraphy of the Upper Pleistocene-Holocene valley deposits of the middle Sikhote Alin (with reference to the Bolotisty placer field in the upper reaches of the Khor River). Vestnik Severo-Vostochnogo Nauchnogo Tsentra, FEB RAS 1:20-31 (in Russian). [Белянин П.С., Иванов В.В., Аеснов С.В., Белянина Н.И., Арсланов Х.А., Максимов Ф.Е. 2018. Биостратиграфия верхнеплейстоцен-голоценовых Аолинных отложений среднего Сихотэ-А^иня (на примере Болотистого россыпного поля в верховьях p. Хор) // Вестник Северо-Восточного научного центра $\triangle$ ВО РАН. №1. С. 20-31].

Belyanina, N.I. 2005. Stratigraphy of the Late Pleistocene - Holocene sediments in the Ussuri drainage basin. Proceedings of XI All-Russian Palynological Conference "Palynology: theory and applications": 27.09-01.10. 2005. ARES printing office, Moscow (in Russian). ББелянина Н.И. 2005. Стратиграфия отложений позАнего плейстоцена-гомоцена бассейна р. Уссури. // XI Всероссийская паминологическая конференция «Палинология: теория и практика». М.: Типография АРЕС. С. 31]. 
Chun, L.J. 1994. The broadleaved Korean pine forest in China. In: Proceedings of the International Workshop on Subalpine Stone Pines and their Environment: The Status of our Knowledge, pp. 81-84. US Department of Agriculture, Ogden, UT.

Danko, L.V., E.V. Bezrukova \& L.A. Orlova 2009. Reconstruction of the evolution of the Primorsky Ridge geosystems the the 2 nd half of the Holocene. Geographiya $i$ Prirodnye Resursy 3:48-55 (in Russian). [Аанько М.В., Безрукова Е.В., Орлова А.А. 2009. Реконструкция развития геосистем Приморского хребта во второй половине голоцена // География и природные ресурсы. № 3. C. 48-55].

Farjon, A. 2010. A handbook of the world's conifers. Koninklijke Brill, Leiden, Boston, 1111 pp.

Golubeva, L.V. \& L.P. Karaulova 1983. Vegetation and climatic stratigraphy of the Pleistocene and Holocene of the southern Far East. Trudy Geologicheskogo Instituta AN USSR 366: 1-143 (in Russian). ГГолубева А.В., Караулова А.П. 1983. Растительность и климатостратиграфия плейстоцена и голоцена юга Аальнего Востока // Труды ГИН. Вып. 366. 143 с.].

Hershberg, L.B., E.V. Mikhailik, V.S. Pushkar \& B.I. Vachaev 2013. Structure and composition of the clayey series on the shelf of the southern Primorye region and the prospects for its development. Tikhookeanskaya Geologiya 23(2):90-99 (in Russian). [Хершберг А.Б., Михаймик Е.В., Пушкарь В.С., Вачаев Б.И. 2013. Строение, вещественный состав илистой толщи шельфа Юга Приморья и перспективы ее освоения // Тихоокеанская геология. Т. 23, № 2. С. 90-99].

Igarashi, Y. 1993. History of environmental change in Hokkaido from the viewpoint of palynological research. In: Biodiversity and Ecology in the Northernmost Japan (S. Higashi, A. Osawa \& K. Kanagawa, eds), pp. 1-19. Hokkaido University Press, Sapporo.

Igarashi, Y. 1996. Lateral climatic reversion in Hokkaido, Northeast Asia, inferred from Larix pollen record. Quaternary Science Review 15:989-995.

Kabanov, N.E. 1977. Coniferous trees and shrubs in the Far East. Nauka, Moscow, 175 pp. (in Russian). [Кабанов H.E. 1977. Хвойные деревья и кустарники Аальнего Востока. М.: Наука. 175 с.].

Khotinsky, N.A. 1977. The Holocene of Northern Eurasia. Nauka, Moscow. 200 pp. (in Russian). [Хотинский H.A. 1977. Голоцен Северной Евразии. М.: Наука. 200 с.].

Kolesnikov, B.P. 1954. Korean pine in the Soviet Far East. Komarovskiye cbteniya 4: 23-67 (in Russian). [Колесников Б.П. 1954. Корейский кеАр на советском АаАьнем Востоке // Комаровские чтения. Вып. 4. С. 23-67].

Kolesnikov B.P. 1956. Korean pine forsts in the south of the Far East. USSR Academy of Sciences Publishing House, Moscow, Leningrad, 261 pp. (in Russian). [Колесников Б.П. 1956. Кедровые меса Аальнего Востока. М.; А.: Иза-во АН СССР, 261 с.].

Komarov, V.L. 1949. Selected Works. Flora of Manchuria. Part 1. USSR Academy of Sciences Publishing House, Moscow, Leningrad, 528 pp. (in Russian). [Комаров B. $\Lambda$. Избранные сочинения. ФАора Маньчжурии, Ч. 1. М.;

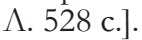

Korotky, A.M. 2002. Palynological characteristics and radiocarbon dates of the Upper Quaternary deposits in the Russian Far East (the lower reaches of the Amur River, Primorye, Sakhalin Island, the Kuriles). In: Late Quater- nary vegetation and climate of Siberia and the Russian Far East (palynological and radiocarbon database) (P.M. Anderson \& A.V. Lozhkin, eds), pp. 257-369, Magadan. (in Russian). [Koроткий А.М. 2002. Палинологические характеристики и радиоуглеродные Аатировки верхнечетвертичных отложений российского АаАьнего Востока (низовья р. Амур, Приморье, о. Сахалин, Курильские острова) // Позднечетвертичные растительность и климаты Сибири и Российского Аальнего Востока (палинологическая и радиоуглеродная база данных). Магадан: СВНЦ АВО РАН. C. 257-369].

Korotky, A.M., P.M. Anderson, A.V. Lozhkin, T.V. Matrosova, T.B. Solomatkina, T.A. Braun, L.B. Brubaker, T.A. Grebennikova, L.M. Mokhova \& F.S. Hu 2005. Specific features of the environmental evolution of the Sikhote Alin Range (Primorye Territory) in the Holocene inferred from lacustrine sediments. In: Moments from the Quaternary history of Northeast Asia. North East Interdisciplinary Research Institute, Far Eastern Branch, Russian Academy of Sciences, Magadan, 87 pp. (in Russian). [Короткий А.М., Андерсон П.М., Аожкин А.В., Матросова Т.В., Соломаткина Т.Б., Браун Т.А., Брубейкер А.Б., Гребенникова Т.А, Мохова А.М., Ху Ф.С. 2005. Особенности эволюции природной среды хр. Сихотэ-Алинь (Приморский край) в голоцене по Аанным озерных отложений // Страницы четвертичной истории Северо-Восточной Азии. Магадан: СВКНИИ АВО РАН. 87 с.].

Korotky, A.M., L.P. Karaulova \& T.S. Troitskaya 1980. Quaternary deposits of the Primorye. Stratigraphy and Paleogeography. Nauka, Novosibirsk, 234 pp. (in Russian). [Короткий А.М., Караулова А.П., Троицкая Т.С. 1980. Четвертичные отложения Приморья: Стратиграфия и памеогеография. Новосибирск: Наука. 234 с.].

Korotky, A.M., V.G. Volkov, T.A. Grebennikova, N.G. Razjigaeva, V.S. Pushkar, L.A. Ganzey \& L.M. Mokhova 1999. The Far East. In: Climate and environment changes during the last 65 million years (Cenozoic: from Paleocene to Holocene) (A.A. Velichko, ed.), pp. 146-164, GEOS Publishing House, Moscow (in Russian). [Короткий A.M., Волков В.Г., Гребенникова Т.А., Разжигаева Н.Г., Пушкарь В.С., Ганзей А.А., Мохова А.М. 1999. АаАьний Восток // Изменение климата и ландшафтов за последние 65 милиионов Ает (кайнозой: от палеоцена Ао голоцена). M.: ГEOC. C. 146-164].

Krestov, P.V. 2003. Forest vegetation of Easternmost Russia (Russian Far East). In: Forest Vegetation of Northeast Asia (J. Kolbek, M. Srutek \& E.O. Box, eds), pp. 91-179. Kluwer, Dordrecht.

Krestov, P.V., J.S. Song, Y. Nakamura \& V.P. Verkholat 2006. A phytosociological survey of the deciduous temperate forests of mainland Northeast Asia. Phytocoenologia 36(1): 77-150.

Li, C., Y. Wu \& X. Hou 2011. Holocene vegetation and climate in Northeast China revealed from Jingbo Lake sediment. Quaternary International 229: 67-73.

Lyashchevskaya, M.S. 2016. Landscape and climate changes on islands in the Peter the Great Gulf (Sea of Japan) over the last 20000 years. Uspekhi sovremennogo estesvoznaniya 11:372-379 (in Russian). [Аящевская М.С. 2016. АанАшафтно-климатические изменения на островах замива Петра Великого (Японское море) за последние 20000 мет // Успехи современного естествознания. № 11. C. 372-379].

Mikishin, Y.A., T.I. Petrenko, I.G. Gvozdeva \& A.N. Popov 2008. Evolution of landscapes in Khasansky District 
(Southwest Primorye) in Late Pleistocene - Holocene. In: Proceedings of International Symposium "Human Ecosystem Changes in the Northern Circum Japan Sea Area (NCJSA) in Late Pleistocene, pp. 82-94, Tokyo.

Nakamura, Y. \& P.V. Krestov 2005. Coniferous forests of the temperate zone of Asia. In: Coniferous forests. (Ecosystems of the World 6) (F. Andersson, ed.), pp. 163-220, Elsevier, New York, London, Paris.

Neushtadt, M.I. 1952. On the Korean pine in the Soviet Far East as a relict from the Tertiary. Doklady Academii Nauk. SSSR 86(2):425-428 (in Russian). [НейштаАт М.И. 1952. О корейском кедре на советском Аальнем Востоке как "реликте" третичного времени // Аоклады АН СССР. Т. 86, № 2. С. 425-428].

Ohwi, J. 1965. Flora of Japan. Switsonian Inst., Washington, 1067 pp.

Pavlyutkin, B.I. \& N.I. Belyanina 2002. Quaternary deposits of the Prymorye Region: some results of systematization and prospects for future studies. Tikhookeanskaya Geologiya 21(3):80-93 (in Russian). [Павлюткин Б.И., Белянина Н.И. 2002. Четвертичные отложения Приморья: некоторые итоги систематизации и АаАьнейшие перспективы изучения // Тихоокеанская геология. Т. 21, № 3. C. 80-93].

Pavlyutkin, B.I., V.S. Pushkar, N.I. Belyanina, N.A. Okovitaya \& L.A. Lobanova 1984. The Holocene deposts in the Razdolnaya River drainage basin (south-western Primorye). In: Paleogeographic boundaries and approaches to their studies (A.M. Korotky \& V.S. Pushkar, eds), pp. 43-53, North-East Reasearch Center, the USSR Academy of Sciences, Vladivostok (in Russian). [Павлюткин Б.И., Пушкарь В.С., Бемянина Н.И. Оковитая Н.А., Аобанова А.А. 1984. Голоценовые отложения бассейна р. Раздольной (юго-западное Приморье) // Палеогеографические рубежи и методы их изучения. ВАадивосток: АВНЦ АН СССР. С. 43-53].

Pokrovskaya, I.M. 1950. Pollen analysis. Gosgeolitizdat, Moscow, 571 pp. (in Russian). ППокровская И.M. 1950. Пыльцевой анализ. Москва: Госгеолиздат. 571 с.].

Razjigaeva, N.G., L.A. Ganzey, T.A. Grebennikova, L.M. Mokhova, E.P. Kudryavtseva, Kh.A. Arslanov, F.E. Maksimov \& A.A. Starikova 2018. Landscape and environmental changes along the Eastern Primorye coast during the Middle to Late Holocene and human effects. Journal of Asian Earth Sciences 158: 160-172.

Razjigaeva, N.G., L.A. Ganzey, L.M. Mokhova, T.A. Grebennikova, A.M. Panichev, T.A. Kopoteva, E.P. Kudryavtseva, Kh.A. Arslanov, F.E. Maksimov, A.A. Starikova \& A.Yu. Petrov 2017. Stages of the landscape development on the Sikhote Alin western macro-slope at the Pleistocene-Holocene boundary (the Bikin River drainage basin). Geographiya i Prirodnye Resursy 3: 127-138 (in Russian). Разжигаева Н.Г., Ганзей А.А., Мохова А.М., Гребенникова Т.А., Паничев А.М., Копотева Т.А., Кудрявцева Е.П., Арсланов Х.А., Максимов Ф.Е., Старикова А.А., Петров А.Ю. 2017. Этапы развития мандшафтов западного макросклона Сихотэ-Алиня на рубеже плейстоцена-голоцена (бассейн реки Бикин) // География и природные ресурсы. № 3. С. 127-138].

Razjigaeva, N.G., L.A. Ganzey, L.M. Mokhova, T.P. Makarova, A.M. Panichev, E.P. Kudryavtseva, Kh.A. Arslanov, F.E. Maksimov \& A.A. Starikova 2016. Evolution of the environments on Skotovo Plateau, Sikhote Alin, in the Late Holocene. Izvestiya Rossiiskoi Akademii Nauk, Seriya Geograficheskaya 3: 65-80 (in Russian). [Разжигаева Н.Г.,
Ганзей А.А., Мохова А.М., Макарова Т.Р., Паничев А.М., Кудрявцева Е.П., Арсланов Х.А., Максимов Ф.Е., Старикова А.А. 2016. Развитие кандшафтов Шкотовского плато Сихотэ-Алиня в позАнем голоцене // Известия РАН. Серия географическая. № 3. C. 65-80].

Shumova, G.M. \& V.A. Klimanov 1989. The Late Glacial and Holocene vegetation and climate in the coastal zone of the middle Primorye. In: Paleoclimates of the Late Glacial and Holocene (N.A. Khotinsky, ed.), pp. 154-160, Nauka, Moscow (in Russian). [Шумова Г.М., Климанов В.А. 1989. Растительность и климат позАнеледниковья и голоцена прибрежной зоны среднего Приморья // Палеоклиматы познеледниковья и голоцена. М.: Наука. С. 154-160].

Sohn, P.K. 1984. The paleoenvironment of middle and upper Pleistocene Korea. In: The Evolution of the East Asian Environment (R.P. Whyte, ed.), pp. 877-893, Univ. Hong Kong, Hong Kong.

Solovyev, K.P. 1958. Far Eastern Korean pine-broadleaved forests and their management. Khabarovsk publishing house, Khabarovsk, 367 pp. (in Russian). [Сомовьев К.П. 1958. Кедрово-широколиственные меса Аальнего Востока и хозяйство в них. Хабаровск: Хабаровское книжное изАательство. 367 с.].

Stebich, M., K. Rehfeld, F. Schlütz, P.E. Tarasov, J. Liu \& J. Mingram 2015. Holocene vegetation and climate dynamic of NE China based on the pollen record from Sihailongwan Maar Lake // Quaternary Science Reviews 124: 275-289.

Troitskiy, S.L. 1979. Marine Pleistocene of the Siberian plains. Stratigraphy. Nauka, Novosibirsk, 298 pp. (in Russian). [Троицкий С.А. 1979. Морской плейстоцен Сибирских равнин. Стратиграфия. Новосибирск: Наука, Сибирское отАеление. 298 с.].

Thomas, P. \& A. Farjon 2013. Pinus koraiensis. The IUCN Red List of Threatened Species 2013: e.T42373A2975987. Available from: http://www/calpalonline.de/cgi-bin/ quickcal.pl. Last accessed 24.07.2018.

Tsukada, M. 1984. A vegetation map of the Japanese Archipelago approximately 20000 years BP. Japanese Journal of Ecology 34: 203-208.

Urusov, V.M. 1999. Pines and pine forests of the Russian Far East. Pacific Institute of Geography FEB RAS, Vladivostok, 385 pp. (in Russian). УУ русов B.M. 1999. Сосны и сосняки Аальнего Востока. ВАадивосток: Тихоокеанский институт географии $\triangle \mathrm{BO}$ РАН. 385 с.].

Velichko, A.A. 2012. Evolutionary Geography: problems and solutions. GEOS, Moscow, 564 pp. (in Russian). [Величко А.А. 2012. Эволюционная география: проблемы и решения. М.: ГЕОС. 563 с.].

Walker, M.J.C., M. Berkelhammer, S. Björck, L.C. Cwynar, D.A. Fisher, A.J. Long, J.J. Lowe, R.M. Newnham, S.O. Rasmussen \& H. Weiss 2012. Formal subdivision of the Holocene Series/Epoch: a discussion paper by a Working Group of INTIMATE (Integration of ice-core marine and terrestrial records) and the Subcommission on Quaternary Stratigraphy (International Commission on Stratigraphy). Journal of Quaternary Science 27:649-659.

Wanner, H., J. Beer, J. Butikofer, T.J. Crowley, U. Cubasch, J. Fluckiger, H. Goosse, M. Grosjean, F. Joos, J.O. Kaplan, M. Kuttel, S.A. Muller, I.C. Prentice, O. Solomina, T.F. Stocker, P. Tarasov, M. Wagner \& M. Widmann 2008. Mid- to Late Holocene climate change: an overview. Quaternary Science Reviews 27: 1791-1828. 
Weninger, B., O. Juris \& U. Danzeglocke 2002. Cologne radiocarbon calibration andpaleoclimate research package. CALPAL_A (advanced) in the Ghost of Edinburgh Edition, Universität zu Köln, Institut für Ur- und Frühgeschichte, Radiocarbon Laboratory. Weyertal 125, D-50923. Köln, 2005. Available from: http://www/calpalonline.de/cgibin/quickcal.pl. Last accessed 20.08.2018.
Zhang, J., Y. Zhou, G. Zhou \& C. Xiao 2014. Composition and structure of Pinus koraiensis mixed forest respond to spatial climatic changes. PLoS ONE 9(5): e97192. https://doi.org/10.1371/journal.pone.0097192. 